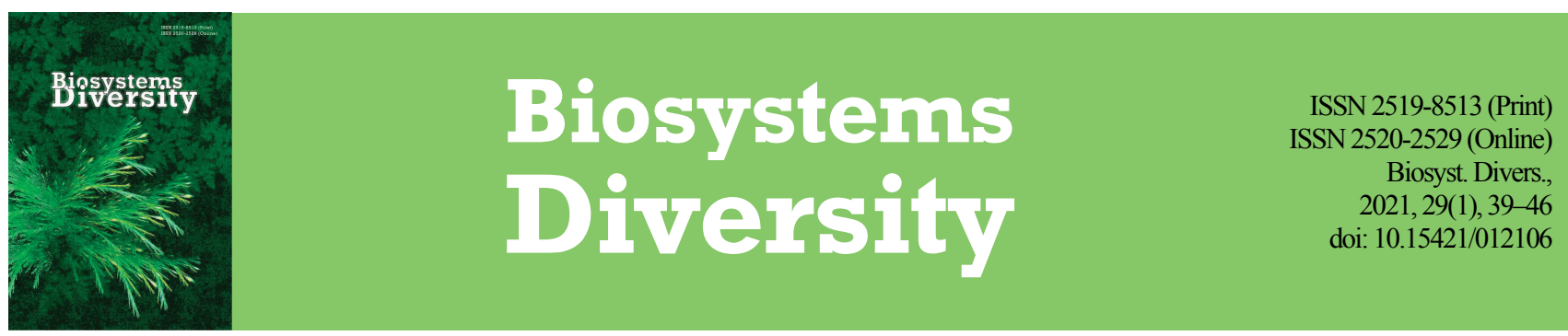

\title{
Nitrite oxidation by phototrophic bacteria of Chlorobium, Thiocapsa and Lamprocystis genera under the influence of inorganic pollutants
}

\author{
O. M. Moroz, G. I. Zvir, S. O. Hnatush \\ Ivan Franko National University of Lviv, Lviv, Ukraine
}

Article info

Received 15.01.2021

Received in revised form 11.02.2021

Accepted 13.02.2021

Ivan Franko National University of Lviv,

Hrushevskyst., 4,

Lviv, 79005, Ukraine

Tel.: +38-067-811-86-44.

E-mail:

oksana.moroz@lmu.edu.u

\author{
Moroz, O. M., Zvir, G. I., \& Hnatush, S. O. (2021). Nitrite oxidation by phototrophic bacteria of Chlorobium, Thiocapsa and Lampro- \\ cystis genera under the influence of inorganic pollutants. Biosystems Diversity, 29(1), 39-46. doi:10.15421/012106
}

Pollutants of inorganic nature (acids, alkalis, mineral salts of different composition, metals) change the course of biological processes of environmental purification, but their influence on the physiological properties of phototrophic sulfur bacteria has not been studied enough. The usage of nitrite ions as an electron donor of anoxygenic photosynthesis by cells of phototrophic green and purple sulfur bacteria Chlorobium limicola IMV K-8, Thiocapsa sp. Ya-2003 and Lamprocystis sp. Ya-2003, isolated from Yavorivske Lake, under the influence of the most widespread inorganic pollutants - hydro- and dihydrophosphates, sulfates, chlorides and chlorates, has been studied. It is shown that $\mathrm{KH}_{2} \mathrm{PO}_{4}, \mathrm{~K}_{2} \mathrm{HPO}_{4}, \mathrm{Na}_{2} \mathrm{SO}_{4}, \mathrm{NaCl}$ and $\mathrm{KClO}_{3}$, present in the van Niel medium with $4.2 \mathrm{mM} \mathrm{NaNO}_{2}$ at concentrations that are 0.5 , 1.0, 2.0, 3.0, 4.0 times different from the maximum permissible concentrations (MPC), influenced the biomass accumulation and nitrite ions oxidation by phototrophic green and purple sulfur bacteria. In media with hydro- and dihydrophosphate ions at concentrations 4.0 times higher than the MPC, inhibition of bacterial growth was up to 1.7 times lower than in the control. The biomass accumulation by bacteria in media with chloride and chlorate ions at concentrations 3.0-4.0 times higher than MPC was 2.0-2.8 times lower compared to the control. In the medium with $\mathrm{Na}_{2} \mathrm{SO}_{4}$ at concentrations 2.0-4.0 times higher than MPC, the biomass was 2.0-4.0 times lower than in the control. Nitrites' oxidation by all strains in the media with the studied pollutants was slowed down. The residual content of nitrite ions in media with hydroand dihydrophosphate, chloride and chlorate ions at their concentrations 4.0 times higher than MPC, exceeded the $\mathrm{NO}_{2}^{-}$content in the control variants up to 1.7 times. If in the medium without pollutants the cells of $C$. limicola IMV K-8, Thiocapsa sp. Ya-2003 and Lamprocystis sp. Ya-2003 strains oxidized $72.7 \%, 72.2 \%$ and $71.4 \%$, respectively, of nitrite ions present in the medium, then in the medium with sulfate ions at concentration 4.0 times higher than the MPC, bacteria oxidized nitrite ions only at $39.6 \%, 34.4 \%$ and $27.0 \%$, respectively. Oxidation of a lower quantity of nitrites by phototrophic bacteria in the media with inorganic pollutants led to the production by them of a lower quantity of nitrates. The content of $\mathrm{NO}_{3}{ }^{-}$in the media with hydro-, dihydrophosphate and chlorate ions at all concentrations was up to 1.9 times lower than in the control. In media with sulfate ions at concentrations 2.0-4.0 times higher than MPC and chloride at concentration 4.0 times higher than MPC, the content of nitrate ions was 2.1-4.3 and 2.0 times, respectively, lower than in the control variants. Inorganic pollutants stimulated the synthesis of intracellular carbohydrates in C. limicola IMV K-8. If the content of intracellular glucose in cells grown in the medium without pollutants was $10.3 \mathrm{mg} / \mathrm{g}$ dry cell weight, then in cells grown in media with $\mathrm{K}_{2} \mathrm{HPO}_{4}, \mathrm{KH}_{2} \mathrm{PO}_{4}, \mathrm{Na}_{2} \mathrm{SO}_{4}, \mathrm{NaCl}_{\text {and }} \mathrm{KClO}_{3}$ at concentrations 4.0 times higher than MPC, its content increased by $12.2 \%, 10.7 \%, 51.6 \%, 17.1 \%$ and $35.9 \%$, respectively. The glycogen content in the cells grown in the medium without pollutants was $45.1 \mathrm{mg} / \mathrm{g}$ dry cell weight. Hydro- and dihydrophosphate, chloride and chlorate ions at concentrations 4.0 times higher than MPC stimulated glycogen synthesis in cells by $47.5 \%, 57.6 \%, 67.4 \%$ and $74.6 \%$, respectively. The glycogen content in cells grown in the medium with $\mathrm{Na}_{2} \mathrm{SO}_{4}$ at concentrations 3.0 and 4.0 times higher than MPC increased by $102.9 \%$ and $107.5 \%$, respectively. Therefore, it is established that pollutants of inorganic nature affect the physiological properties of photosynthetic sulfur bacteria and thus change the course of biological processes of environment purification, in particular, from nitrite ions.

Keywords: phototrophic bacteria; nitrites; hydrophosphates; dihydrophosphates; sulfates; chlorides; chlorates.

\section{Introduction}

Phototrophic bacteria are a morphologically diverse group of gramnegative prokaryotes that are widespread in freshwater, marine sediments, and wastewater (Dahl, 2017). They are involved in the global biogeochemical cycles of nitrogen, sulfur and carbon (Middelburg et al., 2000). Phototrophic sulfur bacteria play an important role in restoring the balance of chemical elements in water bodies through the use of $\mathrm{CO}_{2}$ as a carbon source and reduced compounds of sulfur (sulfides, thiosulfates), nitrogen (nitrites), $\mathrm{Fe}(\mathrm{II})$, molecular hydrogen or organic compounds as exogenous electron donors in the process of anoxygenic photosynthesis (Kondratieva, 1989; Schott et al., 2010). This property of bacteria is due to the presence in them of integrated into the cytoplasmic membrane and intracytoplasmic photosynthetic membrane systems light-collecting pigment-protein complexes (antennas), which include bacteriochlorophylls and carotenoids, which absorb photons and transfer excitation energy to photochemical reaction centers (Kondratieva, 1989; Dahl, 2017; Hallenbeck, 2017). The light-collecting system of purple bacteria consists of membrane pro- teins bound to bacteriochlorophyll and carotenoids in stoichiometric amounts. In green phototrophic bacteria this system is localized in chlorosomes, vesicle-like organelles attached to the cytoplasmic membrane from the cytoplasm side by a crystalline basal plate that contain bacteriochlorophyll aggregates in the form of rod-shaped elements surrounded by a lipid monolayer (Lengeler et al., 2005). Photoassimilation of carbon dioxide and some organic compounds through the reductive pentose phosphate cycle by green sulfur bacteria of the genus Chlorobium leads not only to the formation by cells of substances necessary for their growth. Sometimes a synthesis of reserve product in the form of glucose and a product of its polymerization - glycogen can occur (Gorishniy et al., 2008).

In addition to the biological treatment of polluted natural, technogenic water bodies and industrial effluents from hydrogen sulfide, phototrophic green and purple sulfur bacteria play an important role in the formation and accumulation of sulfur deposits. Sulfur can accumulate in the form of intracellular sulfur globules outside the cells of green and inside the cells of purple sulfur bacteria (Garrity et al., 2001; Garrity et al., 2005; Rosenberg et al., 2014). Phototrophic sulfur bacteria are actively involved in the accu- 
mulation of organic substances in water bodies, and also enrich the environment with nitrogen compounds, carrying out fixation of molecular nitrogen (Kondratieva et al., 1989; Proct, 1999; Pimenov et al., 2003).

Anoxygenic phototrophs use nitrogen compounds in assimilation or dissimilation processes. Although ammonium is usually the best nitrogen source for them, some species assimilate nitrate or nitrite ions if ammonium is absent (Olmo-Mira et al., 2006). In the dark, some purple non-sulfur bacteria, such as Rhodopseudomonas spp. and Rhodobacter spp., can use nitrate as an electron acceptor for respiratory ATP generation (Hougardy et al., 2000). Denitrification by purple sulfur bacteria has not been reported so far. Aerobic oxidation of nitrites (aerobic nitrification) is carried out by bacteria of the genera Nitrobacter, Nitrococcus, Nitrospina, Nitrospira (Lengeler et al., 2005), during which electrons from nitrite ions are transferred to oxygen, and $\mathrm{CO}_{2}$ acts only as the carbon source $\left(\mathrm{NO}_{2}^{-}+1 / 2 \mathrm{O}_{2}\right.$ $\rightarrow \mathrm{NO}_{3}{ }^{-}$). Anaerobic oxidation of nitrite ions occurs only with the participation of phototrophs (Griffin et al., 2007). In the process of phototrophic nitrites' oxidation, nitrite ions serve as electron donors for anoxygenic photosynthesis, and the electrons are used for autotrophic $\mathrm{CO}_{2}$ fixation. Nitrite is an intermediate metabolite in three other types of anaerobic energy metabolism: dissimilatory nitrate reduction to ammonia, denitrification to $\mathrm{N}_{2}$, and the 'Anammox' reaction (Morozkina \& Zvyagilskaya, 2007). In these anaerobic processes, nitrite is an electron acceptor and the donors are organic or inorganic compounds. Nitrite oxidation in the process of anoxygenic photosynthesis by strains of purple sulfur bacteria of the Thiocapsa genus (Schott et al., 2010) and by purple non-sulfur bacteria Rhodopseudomonas yavorovii is described (Tarabas et al., 2019). The use by these bacteria of nitrite ions as electron donors is analyzed in detail with respect to their potential role in nitrite oxidation in nature (Schott et al., 2010; Tarabas et al., 2019). The results of 16S rRNA gene analysis indicate that Thiocapsa sp. strain KS1 is closely related to the aerobic nitrite oxidizer Nitrococcus mobilis (Schott et al., 2010). Intracytoplasmic membrane systems of Nitrococcus are very similar to the same structures in phototrophic purple bacteria (Schott et al., 2010; Hemp et al., 2016). The genome of the nitrite-oxidizing phototrophic bacteria Thiocapsa sp. KS1 was sequenced and analyzed. Genes associated with respiration, phototrophy and nitrogen metabolism in these bacteria have been identified (Hemp et al., 2016). The diazotrophic strain Thiocapsa KS1 has a complete set of nif genes whose products are involved in nitrogen fixation including molybdenum-iron nitrogenase (NifDK) and nitrogenase reductase (NifH). Bacteria Thiocapsa KS1 can assimilate ammonium and also uses nitrite and nitrate ions as nitrogen sources (Schott et al., 2010; Hemp et al., 2016).

Nitrite oxidation in Thiocapsa KS1 occurs by the action of Mo-bisMGD-binding nitrite oxidoreductase (NXR), an enzyme that can catalyze nitrite oxidation and nitrate reduction: $\mathrm{NO}_{2}{ }^{-}+\mathrm{H}_{2} \mathrm{O} \leftrightarrow \mathrm{NO}_{3}{ }^{-}+2 \mathrm{e}^{-}+2 \mathrm{H}^{+}$ (Tanaka et al., 1983). The NXR of Thiocapsa KS1 was similar to the NXR forms found in the chemolithotrophic nitrite-oxidizing bacteria (Sorokin et al., 2012) and to the dissimilatory membrane-bound nitrate reductase (NAR) system found in many nitrate-reducing organisms. The NXR complex consisted of the $\alpha$-subunit ( $\mathrm{NxrA}$ ), which contains the catalytic site, $\beta$-subunit (NxrB), which transmits electrons, with four cysteine-rich binding motifs for [Fe-S] clusters and the $\gamma$-subunit (NxrC), a membrane protein that putatively binds two heme $b$ groups. Electrons derived from nitrite flow from NxrA through NxrB to NxrC, which anchors NXR in the membrane and transfers the electrons to the down-stream electron carriers. The NxrA and NxrB subunits are cytoplasm-oriented and similar to the NarGH subunits of bacterial nitrate reductases NARs (Hemp et al., 2016). Reduction of nitrates to nitrites can be carried out by periplasmic nitrate reductase NAR (NapDAGHB). The NXR can function as a membrane-bound NAR. The genome of Thiocapsa KS1 encodes proteins related to hydroxylamine dehydrogenase, which are involved in the nitrites reduction to NO. In addition, the strain Thiocapsa KS1 contains NO and $\mathrm{N}_{2} \mathrm{O}$ reductases, which sequentially reduce $\mathrm{NO}$ to $\mathrm{N}_{2}$ (Hemp et al., 2016).

Compared with other electron donors of anoxygenic photosynthesis, such as organic compounds, $\mathrm{H}_{2} \mathrm{~S}, \mathrm{H}_{2}$ and $\mathrm{Fe}^{2+}$, the nitrite ion is the electron donor with the highest standard redox potential $\left(E_{0}, \mathrm{NO}_{3}{ }^{-} \mathrm{NO}_{2}^{-}=\right.$ $+0.43 \mathrm{~V}$ ) (Lengeler et al., 2005). Electrons released during the exogenous electron donors' oxidation enter the photosynthetic apparatus of purple bacteria via a cytochrome $c_{2}$ or other electron carrier with redox potential $(+0.49 \mathrm{~V})$, close to the redox potential of the reaction centre primary elect- ron donor - dimer of bacteriochlorophyll ( $a$ or $b$ ), reaction center II quinone type (Kozlova et al., 2008). The reaction centers of Chlorobiaceae family members with Fe-S proteins as final electron acceptors have substantially lower redox potentials (+0.24 V) (Madigan et al., 2006), and nitrite oxidation by these bacteria would require reversed electron transport. It is known that pollutants of inorganic nature change the course of biological processes of environmental purification (Kuznetsov et al., 2015; Tarabas et al., 2017), but their influence on the physiological properties of photosynthetic sulfur bacteria has not been studied enough. Therefore, the aim of the study was to investigate the usage of nitrite ions as an electron donor of anoxygenic photosynthesis by cells of phototrophic green and purple sulfur bacteria isolated from the water of Yavorivske Lake under the influence of the most widespread inorganic pollutants - hydro- and dihydrophosphates, sulfates, chlorides and chlorates.

\section{Materials and methods}

Phototrophic green and purple sulfur bacteria Chlorobium limicola IMV K-8, Thiocapsa sp. Ya-2003 and Lamprocystis sp. Ya-2003, isolated by us earlier from Yavorivske Lake, were identified at Microbiology Department of Ivan Franko National University of Lviv (Kit \& Gudz, 2007; Gorishniy et al., 2008). The strain C. limicola IMV K-8 has been stored in the depository of D. K. Zabolotny Institute of Microbiology and Virology of the NAS of Ukraine since 2010.

Bacteria were cultivated under anaerobic conditions and constant lighting for 10 days at temperature $+25 \ldots+28^{\circ} \mathrm{C}$ in van Niel medium (Gudz et al., 2014) of the following composition (g/L): $\mathrm{NH}_{4} \mathrm{Cl}(0.4)$, $\mathrm{MgSO}_{4} \times 7 \mathrm{H}_{2} \mathrm{O}(0.33), \mathrm{KH}_{2} \mathrm{PO}_{4}(0.4), \mathrm{CaCl}_{2} \times 2 \mathrm{H}_{2} \mathrm{O}(0.05), \mathrm{CH}_{3} \mathrm{COONa}$ (2.55), $\mathrm{C}_{3} \mathrm{H}_{3} \mathrm{O}_{3} \mathrm{Na}$ (1.0), $\mathrm{NaNO}_{2}(0.29)$ (4.2 mM - concentration of electron donor in the medium of standard composition), $\mathrm{NaHCO}_{3}(6.0)$, inositol (1.0), vitamin $\mathrm{B}_{12}(0.000005)$, microelements solution $-2 \mathrm{~mL}$. Solutions of $\mathrm{CH}_{3} \mathrm{COONa}, \mathrm{C}_{3} \mathrm{H}_{3} \mathrm{O}_{3} \mathrm{Na}$, inositol, $\mathrm{NaHCO}_{3}, \mathrm{NaNO}_{2}$, vitamin $\mathrm{B}_{12}$ and microelements of the following composition $(\mathrm{g} / \mathrm{L}): \mathrm{FeSO}_{4} \times 7 \mathrm{H}_{2} \mathrm{O}$ (2.0), diluted in $25 \% \mathrm{HCl}, \mathrm{CoCl}_{2} \times 6 \mathrm{H}_{2} \mathrm{O}(0.19), \mathrm{MnCl}_{2} \times 4 \mathrm{H}_{2} \mathrm{O}(0.1)$, $\mathrm{ZnCl}_{2}$ (0.07), $\mathrm{Na}_{2} \mathrm{MoO}_{4} \times 2 \mathrm{H}_{2} \mathrm{O}(0.036), \mathrm{NiCl}_{2} \times 6 \mathrm{H}_{2} \mathrm{O}(0.024), \mathrm{H}_{3} \mathrm{BO}_{3}$ (0.006), $\mathrm{CuCl}_{2} \times 2 \mathrm{H}_{2} \mathrm{O}(0.002)$, were sterilized separately and placed into the medium before seeding of the cells. The $\mathrm{pH}$ of the medium was adjusted to the optimum by phosphoric acid solution (10\%). The $\mathrm{pH}$ value of the medium was slightly alkaline $(\mathrm{pH}-7.5-8.0)$ for purple and neutral $(\mathrm{pH}-7.0)$ - for green sulfur bacteria. Bacteria were sown in the medium to initial cells concentration of $0.2 \mathrm{mg} / \mathrm{mL}$. To create anaerobic conditions, $25 \mathrm{~mL}$ tubes were completely filled with the medium and closed with rubber stoppers. During the cultivation of the cultures the whole day lighting was provided by incandescent lamps with capacity 60-75 W. Purple sulfur bacteria were grown at an illumination of 150-200 lux using a red interference filter that transmits light with a wavelength of more than $800 \mathrm{~nm}$. Green sulfur bacteria were illuminated by rays with a wavelength of $700-800 \mathrm{~nm}$, the illumination was $40 \mathrm{lux}$. The illumination intensity was measured using a lux-meter U-116.

\section{Table 1}

The concentrations of inorganic pollutants in the cultivation medium

\begin{tabular}{|c|c|c|c|c|c|c|}
\hline Compounds & $\begin{array}{l}\text { Maximum permissible } \\
\text { concentrations (MPC) } \\
\text { of pollutants, } \mathrm{mg} / \mathrm{L}\end{array}$ & & Con & centration & $\mathrm{s}, \mathrm{mM}$ & \\
\hline $\begin{array}{c}\text { Difference } \\
\text { between MPC, } \\
\text { times }\end{array}$ & 1 & 0.5 & 1 & 2 & 3 & 4 \\
\hline $\mathrm{K}_{2} \mathrm{HPO}_{4}$ & $3.5^{*}$ & 0.019 & $0.037^{*}$ & 0.074 & 0.111 & 0.148 \\
\hline $\mathrm{KH}_{2} \mathrm{PO}_{4}$ & $3.5^{*}$ & 0.019 & $0.037^{*}$ & 0.074 & 0.111 & 0.148 \\
\hline $\mathrm{Na}_{2} \mathrm{SO}_{4}$ & $500^{*}$ & 2.604 & $5.208^{*}$ & 10.416 & 15.624 & 20.832 \\
\hline $\mathrm{NaCl}$ & $350^{*}$ & 4.930 & $9.859^{*}$ & 19.718 & 29.577 & 39.436 \\
\hline $\mathrm{KClO}_{3}$ & $0.7^{*}$ & 0.004 & $0.008^{*}$ & 0.016 & 0.024 & 0.032 \\
\hline
\end{tabular}

Note: * - the MPC of pollutants (Grushko, 1979; Chlorite and chlorate in drinkingwater. Background document for preparation of WHO Guidelines for drinking-water quality. 2003. World Health Organization, Geneva (WHO/SDE/WSH/03.04/86) www.who.int/water_sanitation_health/dwq/chemicals/chloritesumstat.pdf; Hygienic requirements for drinking water intended for human consumption. Order of the Ministry of Health of Ukraine on approval of State sanitary norms and rules No 400 dated 12.05.2010). 
To study the influence of inorganic pollutants on biomass accumulation, nitrite utilization, nitrate production, synthesis of intracellular carbohydrates, bacteria were sown in test tubes, grown until the middle of the exponential growth phase under anaerobic conditions and optimal illumination in medium with $4.2 \mathrm{mM} \mathrm{NaNO}_{2}$ and inorganic pollutants: $\mathrm{K}_{2} \mathrm{HPO}_{4}, \mathrm{KH}_{2} \mathrm{PO}_{4}, \mathrm{Na}_{2} \mathrm{SO}_{4}, \mathrm{NaCl}, \mathrm{KClO}_{3}$, at concentrations that are 0.5 , 1.0, 2.0, 3.0, 4.0 times different from the maximum permissible (Table 1). Since van Niel medium (excluding microelements) contains dihydrophosphate, sulfate and chloride ions, which are necessary for optimal growth of bacteria at concentrations of 2.094, 0.524 and $5.402 \mathrm{mM}$, respectively, the test compounds, in particular, $\mathrm{KH}_{2} \mathrm{PO}_{4}, \mathrm{Na}_{2} \mathrm{SO}_{4}, \mathrm{NaCl}$, were added to the medium additionally. The control was a medium without pollutants. After 10 days biomass, $\mathrm{NO}_{2}^{-}$and $\mathrm{NO}_{3}^{-}$content in the cultural liquid, glucose and glycogen content in cell-free extracts were determined. Biomass was
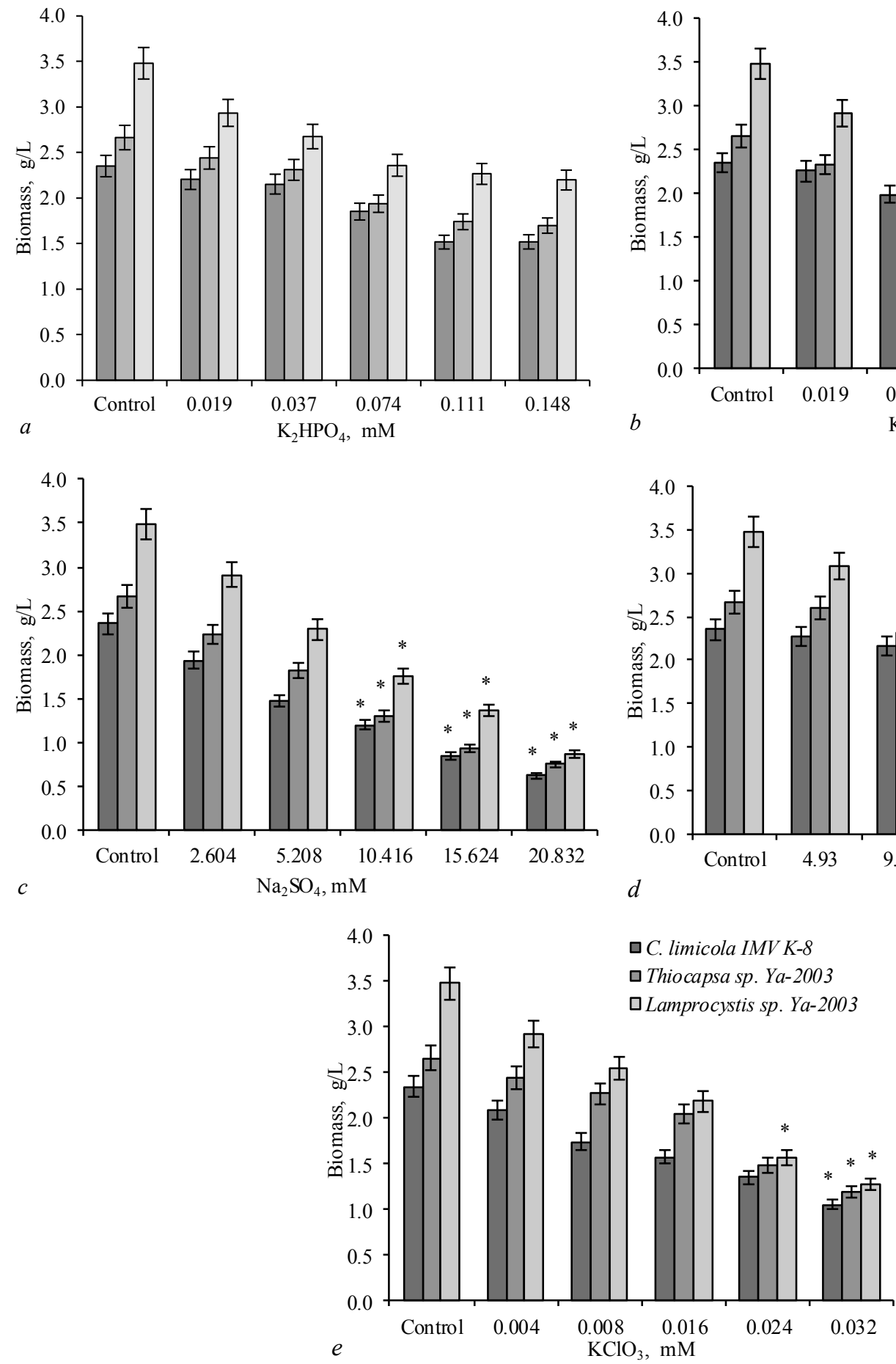

Fig. 1. The influence of $\mathrm{KH}_{2} \mathrm{PO}_{4}(a), \mathrm{K}_{2} \mathrm{HPO}_{4}(b), \mathrm{Na}_{2} \mathrm{SO}_{4}(c), \mathrm{NaCl}(d)$ and $\mathrm{KClO}_{3}(e)$ on biomass accumulation by phototrophic bacteria in the medium with $4.2 \mathrm{mM} \mathrm{NaNO}_{2}$ on 10 -th day of cultivation $(\mathrm{x} \pm \mathrm{SD}, \mathrm{n}=3)$ : control - the medium without pollutants; $*-$ the data were statistically significant as compared with the control $(\mathrm{P}<0.05)$ determined by the turbidimetric method using the photoelectrocolorimeter KFK-3 by the optical density of the cell suspension (optical way $1=3$ $\mathrm{mm}$ ) by measuring it at wavelengths $\lambda=450 \mathrm{~nm}$ to green and $660 \mathrm{~nm}$ to purple sulfur bacteria and calculated using the formula: $\mathrm{C}, \mathrm{g} / \mathrm{L}=(\mathrm{E} \times \mathrm{n}) / \mathrm{K}$, where $\mathrm{E}$ - extinction; $\mathrm{n}$ - dilution factor, times; $\mathrm{K}$ - coefficient of recalculation, obtained from the calibration curve of the dependence of extinction from the mass of dry cells, determined by the weight method, and equal 0.131 to green and 0.17 to purple sulfur bacteria (Gudz et al., 2014). In a cultural liquid, separated from the cells by centrifugation ( $4025 \mathrm{~g}, 15 \mathrm{~min}$ ), we determined the concentrations of nitrate ions (after their reduction to nitrites in the presence of $\mathrm{Zn}: \mathrm{MnSO}_{4}(1: 100)$ powder as a reducing agent) and nitrite ions by spectrophotometric method which relies on a diazotization reaction with a Griess reagent (n-(1-naphthyl)ethylenediamine dihydrochloride, sulfanil and acetic acid) (Granger, 1996; Gudz et al., 2014).
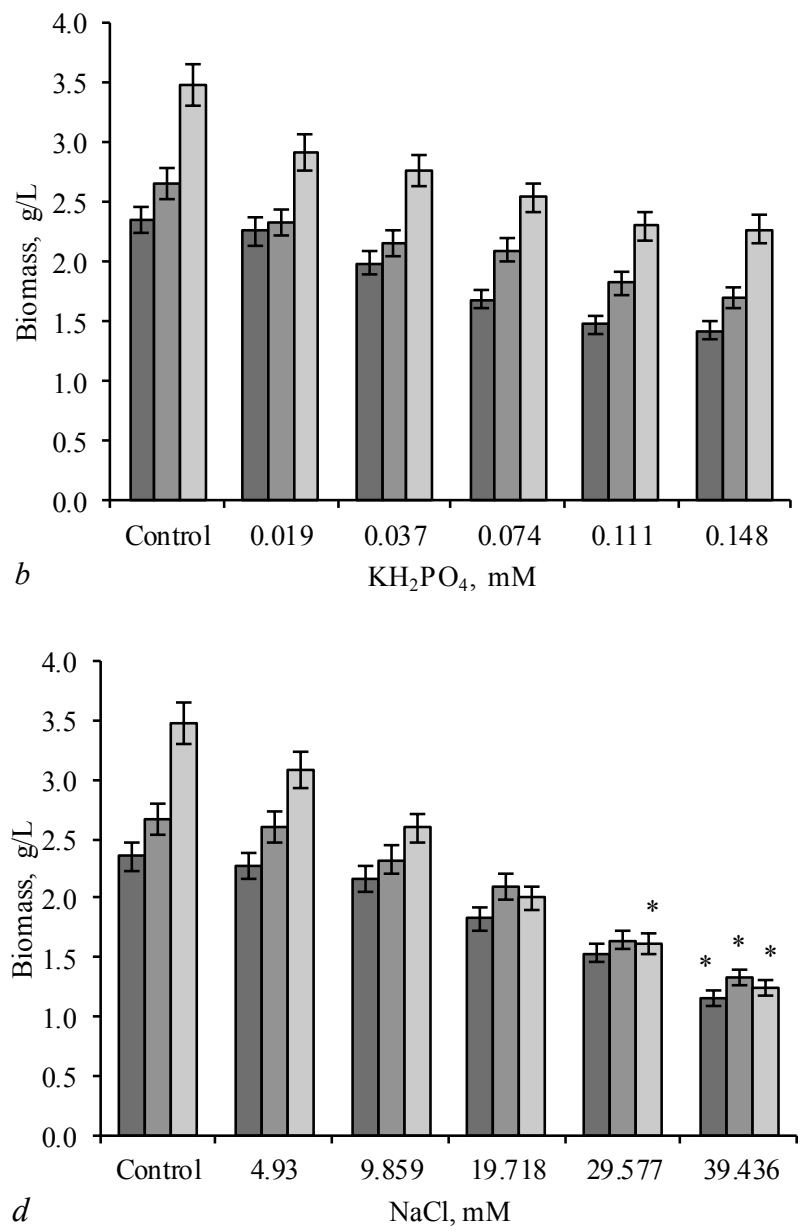

口 C. limicola IMV K-8

口Thiocapsa sp. Ya-2003

口Lamprocystis sp. Ya-2003 
The glucose and glycogen content was determined enzymatically in cell-free extracts of $C$. limicola IMV K-8, using the analytical kit "Diagluc2" (Gonchar, 1998). To determine the concentrations of intracellular glucose and glycogen C. limicola IMV K-8 cells were precipitated at $4025 \mathrm{~g}$ for 30 $\mathrm{min}$. The cultural liquid was drained, the cells were resuspended in $3 \mathrm{~mL}$ of extraction buffer $\left(50 \mathrm{mM}\right.$ potassium phosphate buffer, $\mathrm{pH} 7.5 ; 10^{-5} \mathrm{M}$ EDTA (ethylenediamine tetraacetate); $10^{-5}$ MPMSF (phenylmethylsulfonyl fluoride). Tubes with cells were frozen in a freezer chamber at $-10{ }^{\circ} \mathrm{C}$ and used for preparation of cell-free extracts. Cells were disrupted with an ultrasound disintegrator UZDN-2T at a frequency of $22 \mathrm{kHz}$ for $5 \mathrm{~min}$ in tubes immersed in ice. Cell fragments were separated by centrifugation at $9000 \mathrm{~g}$ for $45 \mathrm{~min}$ at $4^{\circ} \mathrm{C}$. The obtained cell-free extracts were immediately used to determine the content of glucose and glycogen. Glycogen concentration was calculated from the difference in glucose levels before and after acid hydrolysis. Glycogen hydrolysis was performed by boiling cell-free extracts in the

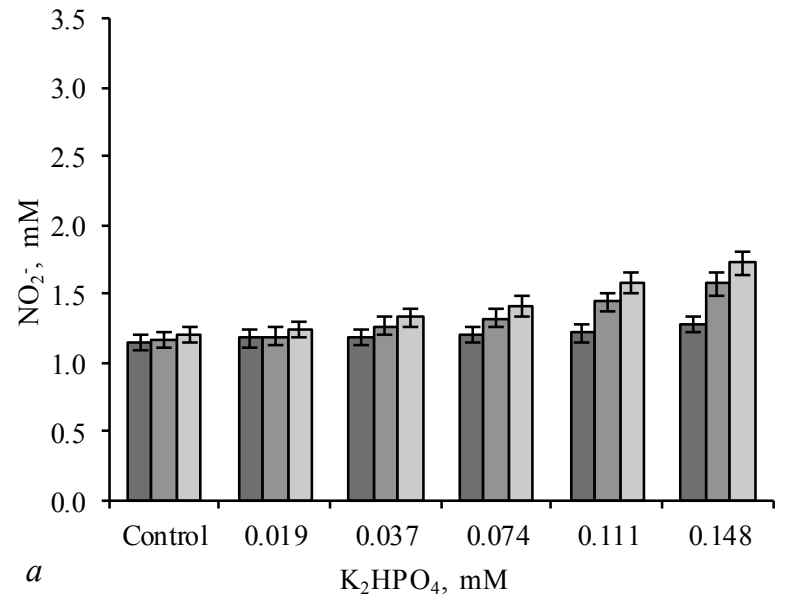

presence of $1 \mathrm{~N} \mathrm{H}_{2} \mathrm{SO}_{4}$ for $3 \mathrm{~h}$ with subsequent neutralization of $\mathrm{Ba}(\mathrm{OH})_{2}$ (Kondratieva et al., 1989). Experiments were repeated three times with three parallel formulations for each variant of experimental and control conditions. Data obtained were expressed as mean $(\mathrm{x}) \pm$ standard deviation (SD) of three measurements. The ANOVA was applied for comparisons of means. Differences were considered significant at $\mathrm{P}<0.05$.

\section{Results}

After 10 days of bacteria growth in the medium with $4.2 \mathrm{mM} \mathrm{NaNO}_{2}$ and $\mathrm{K}_{2} \mathrm{HPO}_{4}, \mathrm{KH}_{2} \mathrm{PO}_{4}, \mathrm{Na}_{2} \mathrm{SO}_{4}, \mathrm{NaCl}$ or $\mathrm{KClO}_{3}$ at concentrations that were $0.5,1.0,2.0,3.0,4.0$ times different from the maximum permissible, the inhibition in varying degrees of biomass accumulation by strains in all experimental variants was observed, compared with controls, which did not contain inorganic pollutants (Fig. 1).
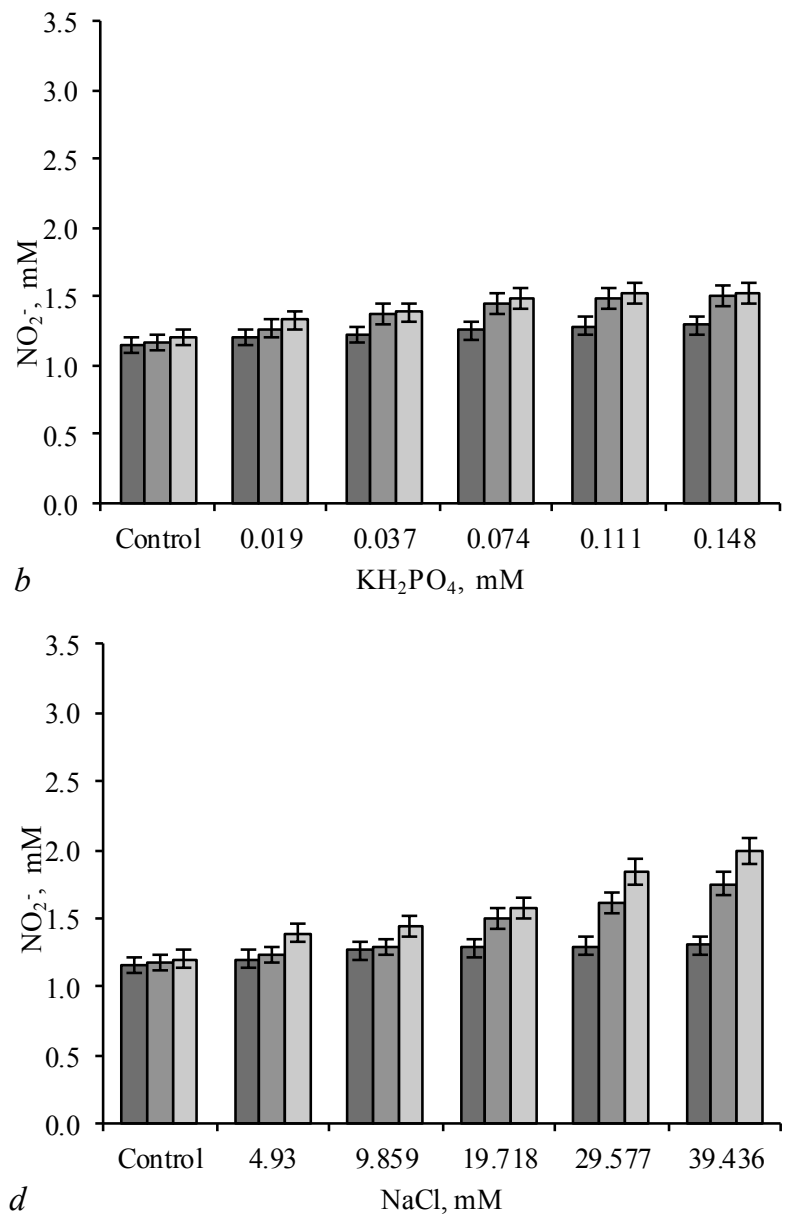

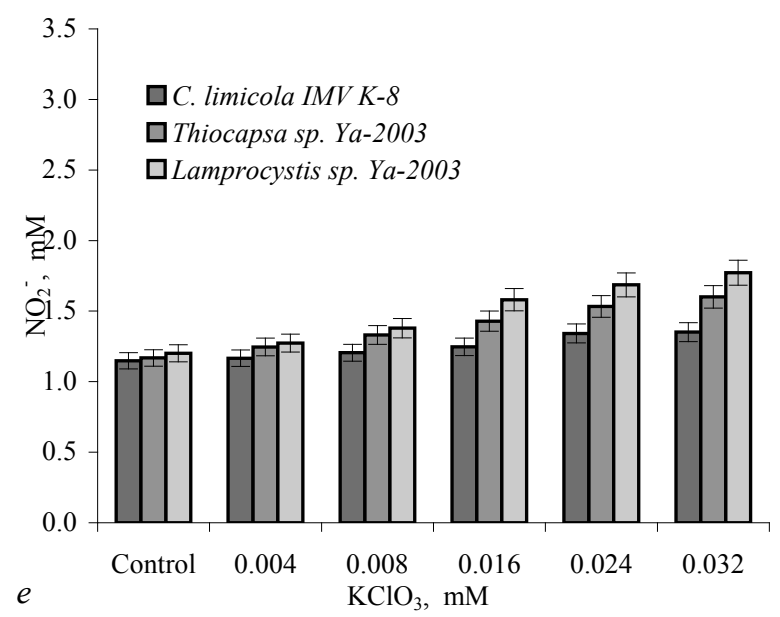

Fig. 2. The concentration of $\mathrm{NO}_{2}^{-}$on 10-th day of cultivation of phototrophic bacteria in the medium with $4.2 \mathrm{mMNaNO}_{2}$ and $\mathrm{KH}_{2} \mathrm{PO}_{4}(a), \mathrm{K}_{2} \mathrm{HPO}_{4}(b)$, $\mathrm{Na}_{2} \mathrm{SO}_{4}(c), \mathrm{NaCl}(d)$ and $\mathrm{KClO}_{3}(e)(\mathrm{x} \pm \mathrm{SD}, \mathrm{n}=3)$ : see Fig. 1 
In media with hydro- and dihydrophosphate ions at all concentrations inhibition of bacteria growth was negligible. The biomass accumulation by bacteria in the media with the highest studied concentration of these compounds -4.0 times higher than the MPC, was only 1.5-1.7 times lower compared to the control. In media with sulfate, chloride and chlorate ions at concentrations 2.0-4.0 times higher than MPC, the biomass accumulation by all strains was significantly reduced. The biomass accumulation by bacteria in media with chloride and chlorate ions at concentrations 3.0-4.0 times higher than MPC was 2.0-2.8 times lower compared to the control. The greatest growth inhibition was observed in the medium with $\mathrm{Na}_{2} \mathrm{SO}_{4}$ at concentrations 2.0-4.0 times higher than MPC, and on day 10 the biomass was 2.0-4.0 times lower than in the control. Oxidation of nitrites by all strains in a medium with $4.2 \mathrm{mM} \mathrm{NaNO}_{2}$ and the investi-
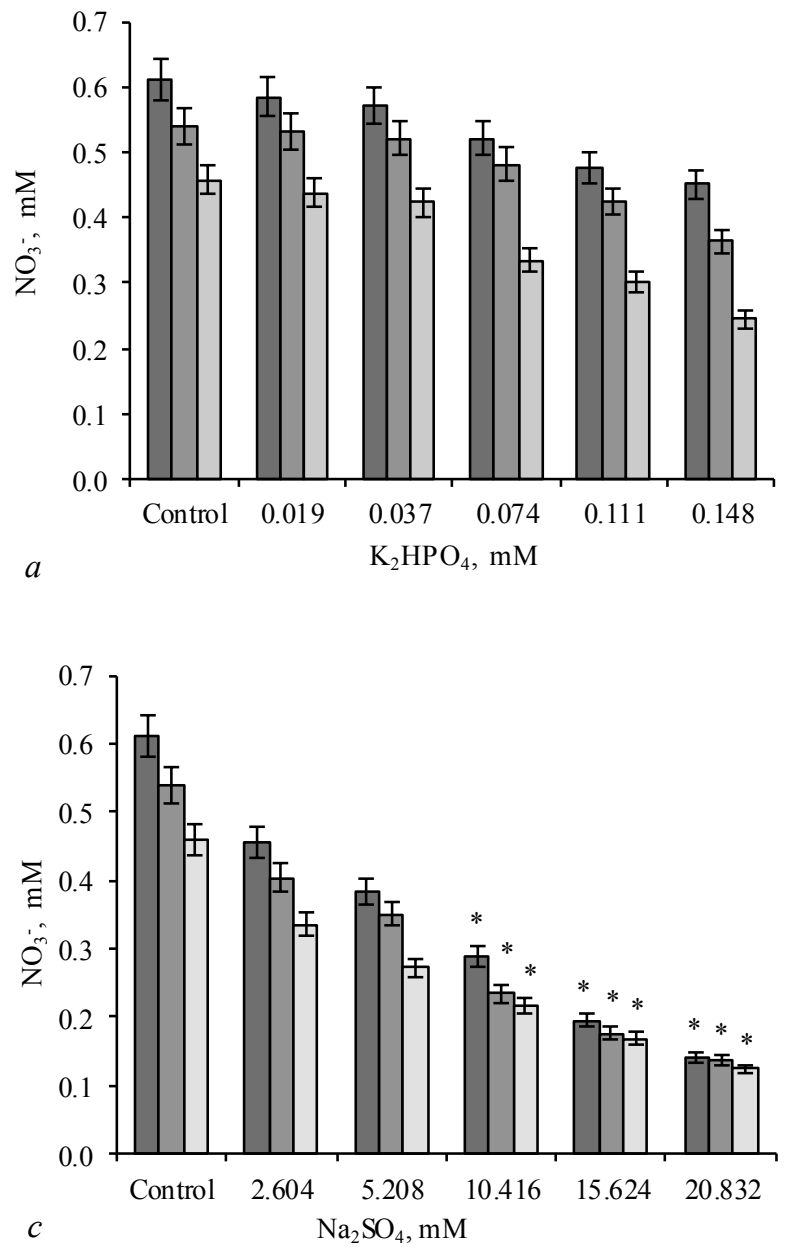

gated pollutants was slowed down (Fig. 2). The residual content of nitrite ions in media with hydro- and dihydrophosphate, chloride and chlorate ions (at their concentrations 4.0 times higher than MPC) for 10 days slightly exceeded the content of $\mathrm{NO}_{2}^{-}$in the control variants, by only $1.1-$ 1.7 times. In the medium with sulfate ions at a concentration equal to the maximum permissible and 2.0-4.0 times higher than MPC, the $\mathrm{NO}_{2}{ }^{-}$ residual content was significantly higher and exceeded the control values by 2.0-2.6 times. If in a medium without pollutants, cells of $C$. limicola IMV K-8, Thiocapsa sp. Ya-2003 and Lamprocystis sp. Ya-2003 strains oxidized $72.7 \%, 72.2 \%$ and $71.4 \%$, respectively, nitrite ions available in the medium, then in the medium with sulfate ions at concentration 4.0 times higher than the MPC bacteria oxidized nitrite ions only at $39.6 \%$, $34.4 \%$ and $27.0 \%$, respectively.
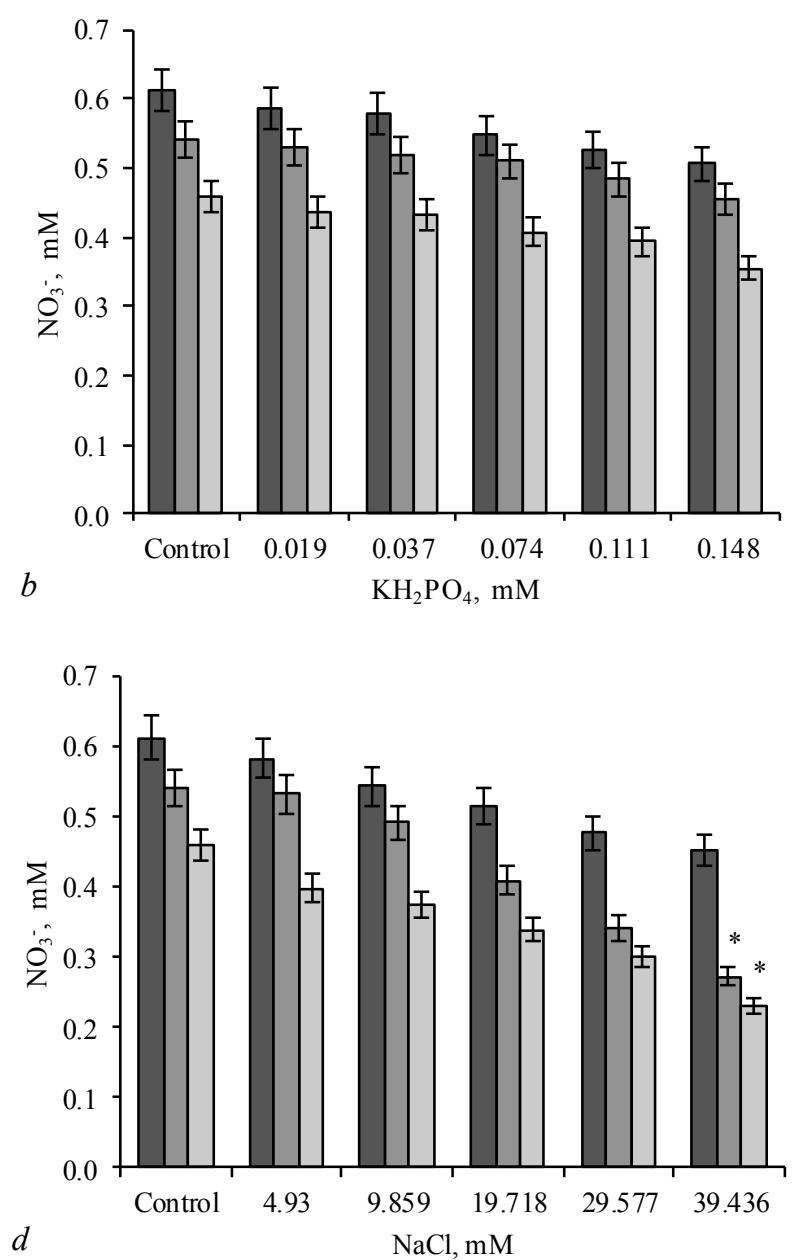

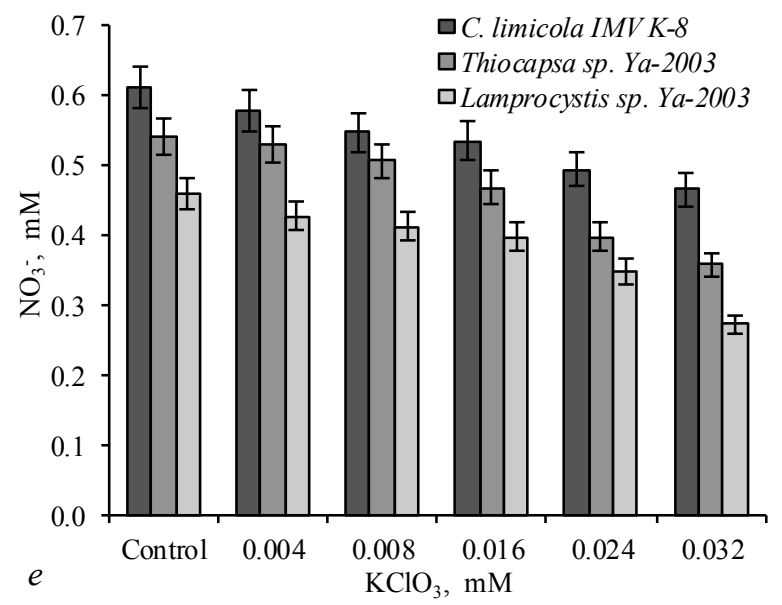

Fig. 3. The concentration of $\mathrm{NO}_{3}^{-}$on 10-th day of cultivation of phototrophic bacteria in the medium with $4.2 \mathrm{mM} \mathrm{NaNO}_{2}$ and $\mathrm{KH}_{2} \mathrm{PO}_{4}(a)$, $\mathrm{K}_{2} \mathrm{HPO}_{4}(b), \mathrm{Na}_{2} \mathrm{SO}_{4}(c), \mathrm{NaCl}(d)$ and $\mathrm{KClO}_{3}(e)(\mathrm{x} \pm \mathrm{SD}, \mathrm{n}=3)$ : see Fig. 1 
Oxidation of a lower quantity of nitrites by cells of all phototrophic bacteria strains in media with inorganic pollutants led to the formation of a lower quantity of nitrates detected in the cultural liquid (Fig. 3). In the medium without pollutants the content of nitrate ions was significantly lower $(0.46-0.61 \mathrm{mM})$ than could theoretically be formed from nitrites, oxidized by cells $(3.00-3.05 \mathrm{mM})$. The concentration of nitrate ions in media with all studied pollutants on day 10 was lower than in the control variants. The content of $\mathrm{NO}_{3}^{-}$in media with of hydro-, dihydrophosphate and chlorate ions at all concentrations slightly (only 1.2-1.9 times) differed from the control. In media with sulfate ions at concentrations $2.0-4.0$ times higher than MPC and chloride ions at concentration 4.0 times higher than MPC, the content of nitrate ions was significantly lower than in the control variants (2.1-4.3 and 2.0 times, respectively). Inorganic pollutants stimulated the synthesis of intracellular carbohydrates in C. limicola IMV
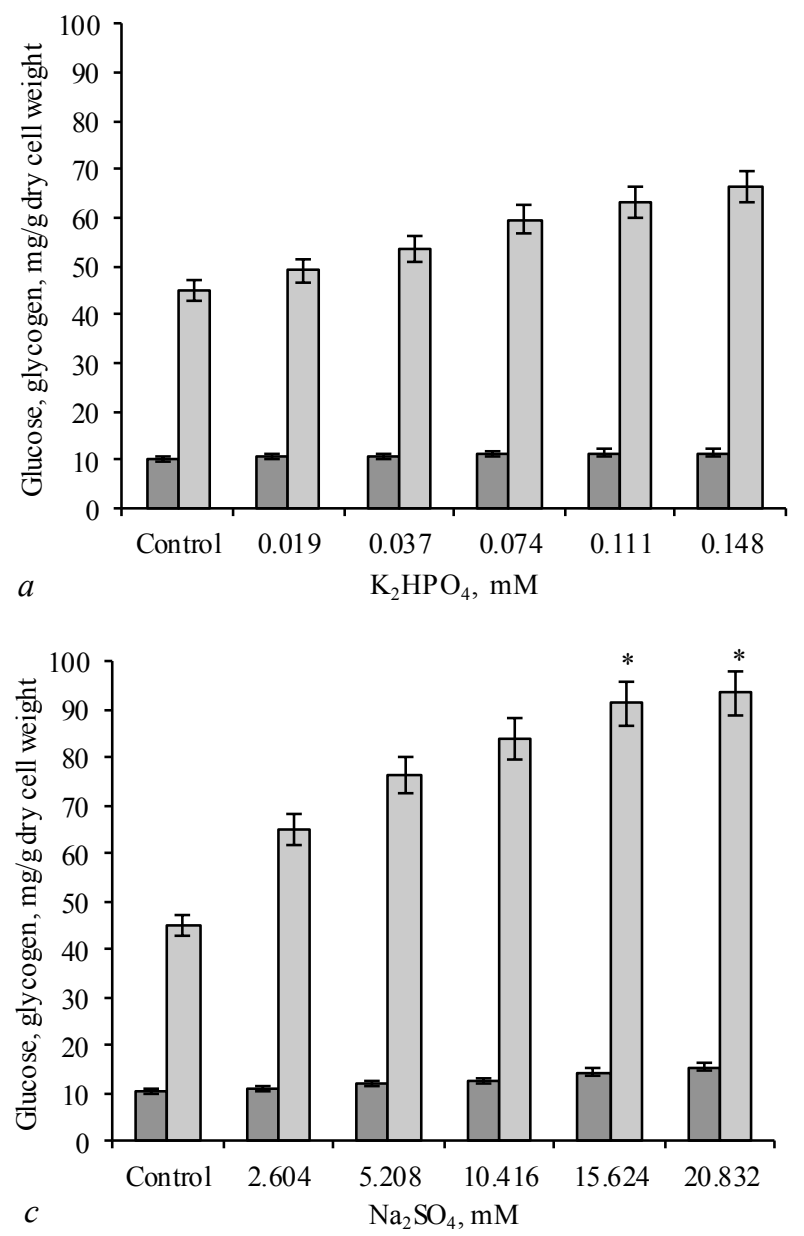

K-8 (Fig. 4). In cells of green phototrophic bacteria grown in media with all investigated toxicants at all concentrations, a slight increase of intracellular glucose content was observed. If the glucose content in cells grown in the medium without pollutants was $10.25 \mathrm{mg} / \mathrm{g}$ dry cell weight, then in cells grown in media with $\mathrm{K}_{2} \mathrm{HPO}_{4}, \mathrm{KH}_{2} \mathrm{PO}_{4}, \mathrm{Na}_{2} \mathrm{SO}_{4}, \mathrm{NaCl}$ and $\mathrm{KClO}_{3}$ at concentrations 4.0 times higher than MPC, its content grew by $12.2 \%$, $10.7 \%, 51.6 \%, 17.1 \%$ and $35.9 \%$, respectively. The glycogen content in the cells grown in the medium without pollutants was $45.09 \mathrm{mg} / \mathrm{g}$ dry cell weight. Hydro- and dihydrophosphate, chloride and chlorate ions at concentrations 4.0 times higher than MPC added into the medium of bacteria cultivation stimulated glycogen synthesis in cells by $47.5 \%, 57.6 \%$, $67.4 \%$ and $74.6 \%$, respectively. The glycogen content in cells grown in the medium with $\mathrm{Na}_{2} \mathrm{SO}_{4}$ at concentrations 3.0 and 4.0 times higher than MPC increased almost twice, by $102.9 \%$ and $107.5 \%$, respectively.
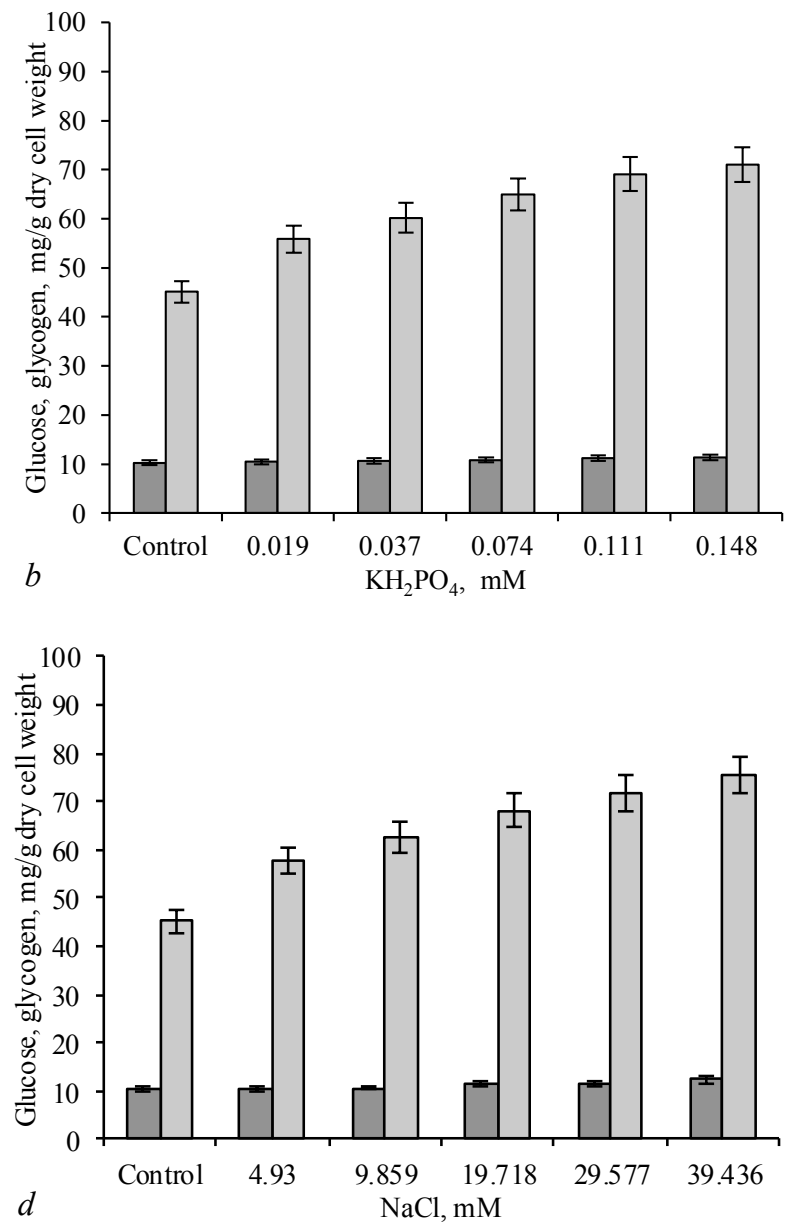

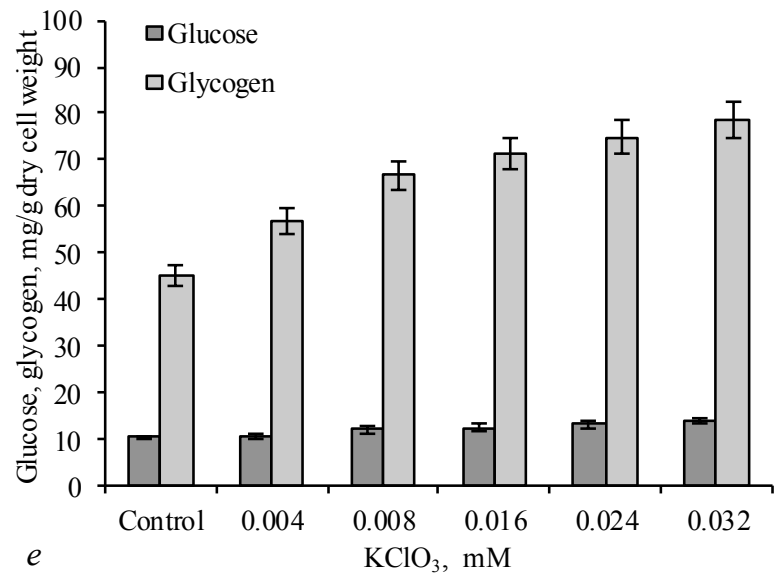

Fig. 4. Intracellular glucose and glycogen content in bacteria $C$. limicola IMV K-8 after 10 days of cultivation in the medium with $4.2 \mathrm{mM} \mathrm{NaNO}$ and $\mathrm{KH}_{2} \mathrm{PO}_{4}(a), \mathrm{K}_{2} \mathrm{HPO}_{4}(b), \mathrm{Na}_{2} \mathrm{SO}_{4}(c), \mathrm{NaCl}(d)$ and $\mathrm{KClO}_{3}(e)(\mathrm{x} \pm \mathrm{SD}, \mathrm{n}=3)$ : see Fig. 1 
Therefore, sulfate ions showed the greatest stimulating effect on the synthesis of intracellular carbohydrates by green phototrophic bacteria, compared with other studied pollutants.

\section{Discussion}

Release of chemical pollutants into the environment is primarily due to the anthropogenic pressure on ecosystems - the increase in industrial production, the use of environmentally hazardous technologies, the accumulation of fertilizers, pesticides, toxic waste and so on. Chemical water pollution occurs due to the inflow of harmful impurities with wastewater of inorganic (acids, alkalis, mineral salts of various composition, metals) and organic origin (oil and petroleum products, detergents, etc.) (Camargo \& Alonso, 2006; Karabyn et al., 2019; Shuryhin et al., 2020). Due to physiological and genetic features, microorganisms respond faster than other organisms to changes in the environment quality and the action of stress factors.

Photolithotrophic sulfur bacteria carry out detoxification of water bodies not only from $\mathrm{H}_{2} \mathrm{~S}$, but also $\mathrm{NO}_{2}^{-}$, using them as electron donors in the process of anoxygenic photosynthesis. Hydrogen sulfide inhibits the processes of anaerobic respiration in microorganisms, damages the structure of metalloproteins and sulfur-containing proteins, disrupts the mitochondrial respiration in eukaryotes due to depolarization of mitochondrial membranes or inhibition of cytochrome oxidase - a key enzyme in the respiratory chain. Nitrates, nitrites and other oxidized nitrogen compounds (nitrogen oxides, peroxyacetyl nitrates) are among the most dangerous pollutants of the environment. The main toxic effect of nitrates and nitrites on eukaryotes is the conversion of hemoglobin to methemoglobin, which is unable to carry oxygen. In addition, nitrites in eu- and prokaryotic cells cause changes in extracellular and intracellular levels of $\mathrm{Cl}^{-}$and $\mathrm{K}^{+}$, which causes a strong electrolyte imbalance, as well as the formation of N-nitroso compounds (nitrosamines), which are mutagenic and carcinogenic (Camargo \& Alonso, 2006; Kuypers et al., 2018). The efficiency of biological methods of environmental purification depends on the metabolic activity of selected strains of bacteria and their resistance to contaminants.

The inflow of large amounts of phosphorus-containing compounds (orthophosphates, pyro-, meta- and other polyphosphates) and organically bound phosphates into non-flowing water bodies leads to their eutrophication (Krishnaswamy et al., 2011). Active chlorine has a complex influence on various structures of microorganisms: the cytoplasmic membrane, cytoplasmic proteins, genome, as well as respiratory chain enzymes, with blocking SH-groups. Another function of $\mathrm{Cl}^{-}$is $\mathrm{Na}^{+}$homeostasis: the efficiency of $\mathrm{Na}^{+}$export might be enhanced by simultaneous export of $\mathrm{Cl}^{-}$ via the sodium channels (Roessler et al., 2003). Toxic effects of chlorates are due to their reduction to more dangerous chlorides with the participation of microorganisms. Addition of $5 \mathrm{mM} \mathrm{KClO}_{3}$ to the cultivation medium inhibits the oxidation of nitrites by microorganisms (Fang et al., 2018). In response to the toxic effects of excess sulfate ions and osmotic stress, bacteria cease to accumulate biomass, however they still maintain cell functions (Rath et al., 2016).

The results of our research show that the most common pollutants of inorganic nature (hydro- and dihydrophosphates, sulfates, chlorides and chlorates) to varying degrees alter the physiological properties of photosynthetic green and purple sulfur bacteria, isolated from the technogenic Yavorivske Lake, in particular, they reduce the biomass accumulation and usage by bacteria of nitrite ions. Stimulation of the synthesis of intracellular carbohydrates in the cells of green sulfur bacteria by inorganic toxicants also indicates a slowing down of processes of constructive and energy metabolism, because glycogen as a secondary metabolite is a reserve compound.

\section{Conclusion}

Thus, it was established that inorganic pollutants: $\mathrm{K}_{2} \mathrm{HPO}_{4}, \mathrm{KH}_{2} \mathrm{PO}_{4}$, $\mathrm{Na}_{2} \mathrm{SO}_{4}, \mathrm{NaCl}, \mathrm{KClO}_{3}$, at concentrations that are 0.5, 1.0, 2.0, 3.0, 4.0 times different from the maximum permissible, inhibit the biomass accumulation, nitrite ions utilization and nitrate ions formation by green and purple sulfur bacteria $C$. limicola IMV K-8, Thiocapsa sp. Ya-2003 and Lamprocystis sp. Ya-2003, isolated from Yavorivske Lake, during growth in van Niel medium with $\mathrm{NaNO}_{2}$. Pollutants of inorganic nature stimulate the synthesis of intracellular carbohydrates by cells of $C$. limicola IMV K-8. Sulfate ions at concentrations 2.0-4.0 times higher than MPC showed the greatest influence on the change in the properties of phototrophic sulfur bacteria in comparison with other studied toxicants.

\section{References}

Camargo, J., \& Alonso, A. (2006). Ecological and toxicological effects of inorganic nitrogen pollution in aquatic ecosystems: A global assessment. Environment International, 32(6), 831-849.

Dahl, C. (2017). Sulfur metabolism in phototrophic bacteria. In: Hallenbeck, P. C. (Ed.). Modern topics in the phototrophic prokaryotes. Springer, Cham.

Fang, Q., Xu, W., Yan, Z., \& Qian, L. (2018). Effect of potassium chlorate on the treatment of domestic sewage by achieving shortcut nitrification in a constructed rapid infiltration system. International Journal of Environmental Research and Public Health, 15(4), 670-681.

Garrity, G., Brenner, D. J., Krieg, N. R., \& Staley, J. R. (Eds). (2005). Bergey's manual of systematic bacteriology. Vol. 2. The proteobacteria. Part B: The Gammaproteobacteria. Springer, Boston.

Garrity, G. M., Holt, J. G., Overmann, J., Pfennig, N., Gibson, J., \& Gorlenko, V. M. (2001). Phylum BXI. Chlorobi phy. nov. In: Boone, D. R., Castenholz, R. W., Garrity, G. M. (Eds.). Bergey's manual ${ }^{\mathbb{Q}}$ of systematic bacteriology. Springer, New York.

Gonchar, M. V. (1998). Chutlyvyj metod kil'kisnogo vyznachennja peroksydu vodnju ta substrativ oksydaz u biologichnyh ob'jektah [Sensitive method for quantitative determination of hydrogen peroxide and oxidase substrates in biological objects]. The Ukrainian Biochemical Journal, 70(5), 157-163 (in Ukrainian).

Gorishniy, M., Gudz, S., \& Hnatush, S. (2008). Metabolizm gljukozy ta glikogenu u klitynah zelenyh fotosyntezuval'nyh sirkovyh bakterij Chlorobium limicola Ya2002 [Glucose and glycogen metabolism in cells of green photosynthetic sulfur bacteria Chlorobium limicola Ya-2002]. Visnyk of Lviv University, Biological Series, 46, 129-136 (in Ukrainian).

Granger, D. L., Taintor, R. R., Boockvar, K. S., \& Hibbs, J. B. (1996). Measurement of nitrate and nitrite in biological samples using nitrate reductase and Griess reaction. Methods Enzymology, 268, 142-151.

Griffin, B. M., Schott, J., \& Schink, B. (2007). Nitrite, an electron donor for anoxygenic photosynthesis. Science, 316, 1870.

Grushko, Y. M. (1979). Vrednye neorganicheskie soedinenija v promyshlennyh stochnyh vodah [Harmful inorganic compounds in industrial wastewater]. Chemistry, Leningrad (in Russian).

Gudz, S. P., Hnatush, S. O., Yavorska, G. V., Bilinska, I. S., \& Borsukevych, B. M. (2014). Praktykum z mikrobiologiji [Workshop on microbiology]. Ivan Franko National University of Lviv, Lviv (in Ukrainian).

Hallenbeck, P. C. (2017). Metabolism, bioenergetics, and omics. Modern topics in the phototrophic prokaryotes. Springer, Cham.

Hemp, J., Lücker, S., Schott, J., Pace, L. A., Johnson, J. E., Schink, B., Daims, H., \& Fischer, W. W. (2016). Genomics of a phototrophic nitrite oxidizer: Insights into the evolution of photosynthesis and nitrification. The International Society for Microbial Ecology Journal, 10, 2669-2678.

Hougardy, A., Tindall, B. J., \& Klemme, J.-H. (2000). Rhodopseudomonas rhenobacensis sp. nov., a new nitrate-reducing purple non-sulfur bacterium. International Journal of Systematic Bacteriology, 50, 985-992.

Karabyn, V., Popovych, V., Shainoha, I., \& Lazaruk, Y. (2019). Long-term monitoring of oil contamination of profile-differentiated soils on the site of influence of oil-and-gas wells in the central part of the Boryslav-Pokuttya oil-and-gasbearing area. Petroleum and Coal, 61(1), 81-89.

Kit, L. Y., \& Gudz, S. P. (2007). Purpurovi sirkobakteriji z vodojm Javorivs'kogo rodovyshha sirky [Purple sulfur bacteria from reservoirs of the Yavoriv sulfur deposit]. Mikrobiolohichnyi Zhurnal, 69(1), 12-19 (in Ukrainian).

Krishnaswamy, U., Muthusamy, M., \& Perumalsamy, L. (2011). Biological removal of phosphate from synthetic wastewater using bacterial consortium. Iranian Journal of Biotechnology, 9, 37-49.

Kondratieva, E. N., Maksimova, I. V., \& Samojlov, V. D. (1989). Fotosintezirujushhie bakterii [Photosynthetic bacteria]. Moscow University Press, Moscow (in Russian).

Kondratieva, E. N. (1989). Fotosintezirujushhie mikroorganizmy [Photosynthetic microorganisms]. Moscow University Press, Moscow (in Russian).

Kozlova, I. P., Radchenko, O. S., Stepura, L. H., Kondratyuk, T. O., \& PilyashenkoNovokhatnyy, A. I. (2008). Heokhimichna diyalnist mikroorhanizmiv ta yiyi prykladni aspekty [Geochemical activity of microorganisms and its applied aspects]. Naukova Dumka, Kyiv (in Ukrainian).

Kuypers, M., Marchant, H., \& Kartal, B. (2018). The microbial nitrogen-cycling network. Nature Reviews Microbiology, 16(5), 263-276.

Kuznetsov, A., Gradova, N., Lushnikov, S., Éngelkhart, M., Vaysser, T., \& Chebotareva, M. (2015). Prikladnaya ehkobiotekhnologiya [Applied Ecobiotechnology]. Binom, Moscow (in Russian). 
Lengeler, J., Drevs, G., \& Shlegel, G. (Eds.). (2005). Sovremennaya mikrobiologiya. Prokarioty [Contemporary Microbiology. Prokaryotes]. Mir, Moscow (in Russian).

Madigan, M. T., Martinko, J. M., \& Brock, T. D. (2006). Brock biology of microorganisms. Pearson Prentice Hall, New Jersey.

Middelburg, J. J., Barranguet, C., Boschker, H. T. S., Herman, P. M. J., Moens, T., \& Heip, C. H. R. (2000). The fate of intertidal microphytobenthos carbon: An in situ ${ }^{13}$ C-labeling study. Limnology and Oceanography, 45(6), 1224-1234.

Morozkina, E. V., \& Zvyagilskaya, R. A. (2007). Nitrate reductases: Structure, functions, and effect of stress factors. Biochemistry, 72(10), 1151-1161 (in Russian).

Olmo-Mira, M. F., Cabello, P., Pino, C., Martinez-Luque, M., Richardson, D. J., Castillo, F., Roldan, M. D., \& Moreno-Vivian, C. (2006). Expression and characterization of the assimilatory NADH nitrite reductase from the phototrophic bacterium Rhodobacter capsulatus E1F1. Archives of Microbiology, 186, 339-344.

Pimenov, N., Rusanov, I., Karnachuk, O. V., Rogosin, D. I., \& Briantseva, I. (2003). Microbial metabolism of the carbone and sulfur cycle in chira Lake Khakasia. Microbiologia, 72(2), 259-267.

Proct, L. M. (1999). Nitrogen-fixing, photosynthetic, anaerobic bacteria associated with pelagic copepods. Aquatic Microbial Ecology, 12, 105-143.

Rath, K., Maheshwari, A., Bengtson, P., \& Rousk, J. (2016). Comparative toxicities of salts on microbial processes in soil. Applied and Environmental Microbiology, 82(7), 2012-2020.

Roessler, M., Sewald, X., \& Müller, V. (2003). Chloride dependence of growth in bacteria. FEMS Microbiology Letters, 225(1), 161-165.
Rosenberg, E., DeLong, E. F., Lory, S., Stackebrandt, E., \& Thompson, F. (Eds.). (2014). The Procaryotes. Prokaryotic physiology and biochemistry. SpringerVerlag, Berlin, Heidelberg.

Schott, J., Griffin, B. M., \& Schink, B. (2010). Anaerobic phototrophic nitrite oxidation by Thiocapsa sp. strain KS1 and Rhodopseudomonas sp. strain LQ17. Microbiology, 156, 2428-2437.

Shuryhin, V., Rak, Y., \& Karabyn, V. (2020). Analysis of factors and development of methods for managing the environmental and civil safety of transboundary transportation of oil and oil products through pipelines. ScienceRise, 5, 51-56.

Sorokin, D. Y., Lücker, S., Vejmelkova, D., Kostrikina, N. A., Kleerebezem, R., Rijpstra, W. I. C., Damsté, J. S. S., Le Paslier, D., Muyzer, G., Wagner, M., van Loosdrecht, M. C. M., \& Daims, H. (2012). Nitrification expanded: Discovery, physiology and genomics of a nitrite-oxidizing bacterium from the phylum Chloroflexi. The International Society for Microbial Ecology Journal, 6, 2245 2256.

Tanaka, Y., Fukumori, Y., \& Yamanaka, T. (1983). Purification of cytochrome alc1 from Nitrobacter agilis and characterization of nitrite oxidation system of the bacterium. Archives of Microbiology, 135, 265-271.

Tarabas, O. V., Hnatush, S. O., \& Moroz, O. M. (2019). The usage of nitrogen compounds by purple non-sulfur bacteria of the Rhodopsendomonas genus. Regulatory Mechanisms in Biosystems, 10(1), 79-82.

Tarabas, O., Moroz, O., Hnatush, S., Yavorska, G., Zvir, G., \& Kovalchuk, M. (2017). Ekoloho-trofichni hrupy mikroorhanizmiv vody ozera Yavorivs'ke [Ecological trophic groups of microorganisms of Yavorivske lake water]. Visnyk of Lviv University, Biological Series, 76, 166-178 (in Ukrainian). 